\title{
Erratum
}

\section{Effect of bioreactor configuration on substrate uptake by cell suspension cultures of the plant Eschscholtzia californica}

\section{Ronald A. Taticek, Murray Moo-Young, and Raymond L. Legge}

Biochemical Engineering Group, Department of Chemical Engineering, University of Waterloo, Waterloo, Ontario, Canada N2L 3G1

In: Appl Microbiol Biotechnol 33:280-286

On page 285 Table 2 should read as follows (corrections are printed in boldface):

Table 2. Comparison of actual biomass yields from oxygen and maintenance coefficients for oxygen with published values

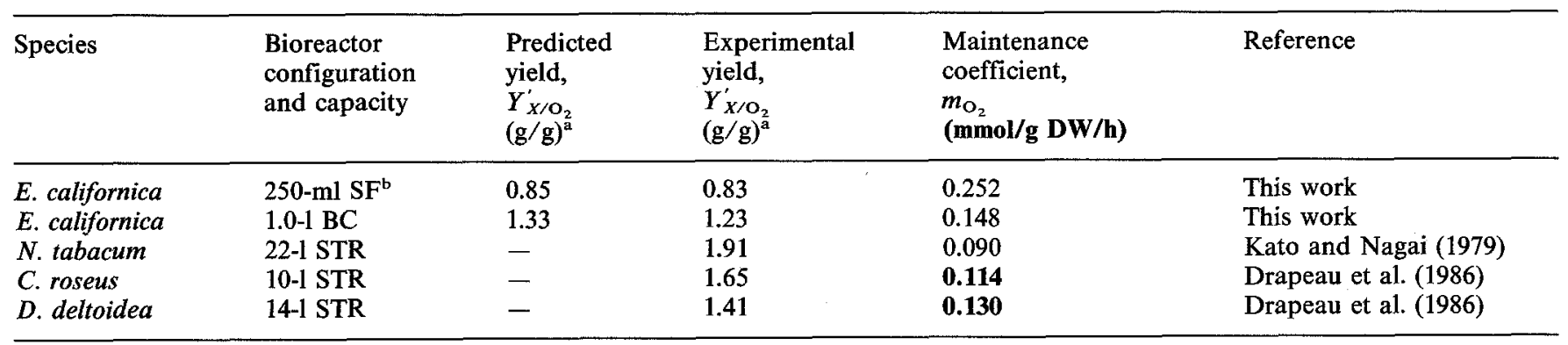

a Grams DW biomass/g oxygen

b See Table 1

Formulas (4) and (5) on page 285 should appear in reversed order as follows:

$$
\begin{gathered}
\mathrm{C}_{6} \mathrm{H}_{12} \mathrm{O}_{6}+2.69 \mathrm{O}_{2}+0.42\left(0.076 \mathrm{NH}_{4}^{+}+0.924 \mathrm{NO}_{3}^{-}\right) \\
\rightarrow 0.51 \mathrm{C}_{5} \mathrm{H}_{10} \mathrm{~N}_{0.83} \mathrm{O}_{4.17}+3.46 \mathrm{CO}_{2}+3.52 \mathrm{H}_{2} \mathrm{O} \\
\mathrm{C}_{6} \mathrm{H}_{12} \mathrm{O}_{6}+2.10 \mathrm{O}_{2}+0.50\left(0.076 \mathrm{NH}_{4}^{+}+0.924 \mathrm{NO}_{3}^{-}\right) \\
\left.\rightarrow 0.60 \mathrm{C}_{5} \mathrm{H}_{10} \mathrm{~N}_{0.83} \mathrm{O}_{4.17}+3.00 \mathrm{CO}_{2}+3.08 \mathrm{H}_{2} \mathrm{O}\right)
\end{gathered}
$$

